\title{
Production characteristics of reactive oxygen/nitrogen species in water using atmospheric pressure discharge plasmas
}

\author{
Kazuhiro Takahashi ${ }^{1 *}$, Kohki Satoh ${ }^{1}$, Hidenori Itoh ${ }^{1}$, Hideki Kawaguchi ${ }^{1}$, \\ Igor Timoshkin², Martin Given², and Scott MacGregor ${ }^{2}$ \\ ${ }^{1}$ Muroran Institute of Technology, Muroran, Hokkaido 050-8585, Japan \\ 2University of Strathclyde, Glasgow G1 1XW, U.K. \\ *E-mail: ktakahashi@mmm.muroran-it.ac.jp \\ Received November 30, 2015; revised January 27, 2016; accepted February 13, 2016; published online xxxx yy, zzzz
}

A pulsed discharge, a DC corona discharge, and a plasma jet are separately generated above a water surface, and reactive oxygen species and reactive nitrogen species (ROS/RNS) in the water are investigated. ROS/RNS in water after the sparging of the off-gas of a packed-bed dielectric barrier discharge (PB-DBD) are also investigated. $\mathrm{H}_{2} \mathrm{O}_{2}, \mathrm{NO}_{2}{ }^{-}$, and $\mathrm{NO}_{3}{ }^{-}$are detected after plasma exposure and only $\mathrm{NO}_{3}{ }^{-}$after off-gas sparging. Short-lifetime species in plasma are found to play an important role in $\mathrm{H}_{2} \mathrm{O}_{2}$ and $\mathrm{NO}_{2}{ }^{-}$production and long-lifetime species in $\mathrm{NO}_{3}{ }^{-}$ production. $\mathrm{NO}_{x}$ may inhibit $\mathrm{H}_{2} \mathrm{O}_{2}$ production through $\mathrm{OH}$ consumption to produce $\mathrm{HNO}_{2}$ and $\mathrm{HNO}_{3} . \mathrm{O}_{3}$ does not contribute to ROS/RNS production. The pulsed plasma exposure is found to be effective for the production of $\mathrm{H}_{2} \mathrm{O}_{2}$ and $\mathrm{NO}_{2}{ }^{-}$, and the off-gas sparging of the PB-DBD for the production of $\mathrm{NO}_{3}^{-}$. (C) 2016 The Japan Society of Applied Physics

\section{Introduction}

23 In recent years, the study of plasma in contact with water has 24 gained increasing attention and the water is known as plasma25 treated water (PTW; also called plasma-activated medium, 26 plasma-activated water, and so on). PTW is produced by 27 various types of discharge plasma such as gliding arc, ${ }^{1-3)}$ 28 plasma jet, ${ }^{4-6)}$ and dielectric barrier discharge. ${ }^{7,8)}$ In general, 29 many kinds of species, such as radicals, ions, and ozone $\left(\mathrm{O}_{3}\right)$, are produced in plasma, and some of the species in the plasma in contact with water act as precursors of reactive oxygen species and reactive nitrogen species (ROS/RNS) in water.

PTW containing the ROS/RNS is applied to various fields such as disinfection, ${ }^{1,3-5,7,8)}$ agriculture, ${ }^{2,9)}$ and plasma medicine. ${ }^{6}$ Several groups suggested that hydrogen peroxide $\left(\mathrm{H}_{2} \mathrm{O}_{2}\right)$, peroxynitrous acid $(\mathrm{HOONO})$, nitrite $\left(\mathrm{NO}_{2}{ }^{-}\right)$, nitric acid $\left(\mathrm{HNO}_{3}\right)$, and/or synergistic effects between these species in water play a key role in bacterial inactivation, plant germination and growth, and chemical and biological effects. Naitali et al. ${ }^{1)}$ reported that PTW and acidified water, containing $0.01 \mathrm{mmol} / \mathrm{L} \quad \mathrm{H}_{2} \mathrm{O}_{2}, \quad 1.6 \mathrm{mmol} / \mathrm{L} \mathrm{NO}_{2}^{-}$, and $0.13 \mathrm{mmol} / \mathrm{L}$ nitrate $\left(\mathrm{NO}_{3}{ }^{-}\right)$, show a lethal effect on Hafnia 44 alvei. Kim et al. ${ }^{3)}$ found that PTW containing $2.94 \mathrm{mmol} / \mathrm{L}$ ${ }_{45} \mathrm{H}_{2} \mathrm{O}_{2}$ contributes to 5-log reduction for Escherichia coli. ${ }_{46}$ Takaki $^{9)}$ reported that water containing $0.12 \mathrm{mmol} / \mathrm{L} \mathrm{NO}_{3}{ }^{-}$ contributes to the improvement of the growth rate of Brassica rapa var. perviridis. Furthermore, Matsui et al. ${ }^{10)}$ also suggested that long-lifetime neutral particles in the gas phase, such as $\mathrm{O}_{3}, \mathrm{H}_{2} \mathrm{O}_{2}$, and $\mathrm{HNO}_{3}$, and synergistic effects between these species play a key role in the disinfection of Geobacillus stearothermophilus spores. To utilize the PTW effectively and efficiently, it is important to control the ROS/ RNS concentration and to clarify the interaction between species in plasma and ROS/RNS in water as well as to investigate efficacy in the application fields, since PTW with a wide-ranging ROS/RNS concentration is used for the investigation of efficacy. Various types of discharge plasma can produce the ROS/RNS; however, few studies have focused on the correlation between the discharge plasma and the ROS/RNS as far as we know.
In this work, we generated a pulsed discharge, a DC 21 corona discharge, an atmospheric pressure plasma jet, and a 22 packed-bed dielectric barrier discharge (PB-DBD) as a 23 plasma source to produce ROS/RNS in water. We exposed 24 deionized water to the pulsed discharge, DC corona dis- 25 charge, or plasma jet. We also sparged the off-gas of the 26 PB-DBD into deionized water. Then, we investigated the 27 concentration and production efficiency of the ROS/RNS in 28 the water.

\section{Experimental procedure}

\subsection{Pulsed discharge}

The experimental apparatus for a pulsed discharge is similar 33 to that used in a previous work. ${ }^{11)}$ A needle electrode and a 34 water bath electrode were placed in a cylindrical discharge 35 chamber to generate the pulsed discharge. The needle 36 electrode was a stainless-steel nail with a diameter of 37 $1.5 \mathrm{~mm}$ and a length of $19 \mathrm{~mm}$, the water bath electrode 38 was made of stainless steel with an inner diameter of 39 $119 \mathrm{~mm}$, a depth of $12 \mathrm{~mm}$, and a capacity of $0.13 \mathrm{~L}$, and the 40 cylindrical chamber was made of acrylic resin with an inner 41 diameter of $140 \mathrm{~mm}$, a height of $100 \mathrm{~mm}$, and a capacity of 42 $1.54 \mathrm{~L}$. Deionized water of $100 \mathrm{~mL}$ was poured into the water 43 bath electrode, and the distance between the tip of the needle 44 electrode and the water surface was fixed at $4 \mathrm{~mm}$. Ar, $\mathrm{N}_{2}, 45$ $\mathrm{O}_{2}$, or a gas mixture of $\mathrm{Ar} / \mathrm{O}_{2}, \mathrm{~N}_{2} / \mathrm{O}_{2}$, or $\mathrm{Ar} / \mathrm{N}_{2}$ was used 46 as a background (BG) gas, and fed into the chamber at a 47 constant flow rate of $5 \mathrm{~L} / \mathrm{min}$. The gas mixture ratios were 48 $\mathrm{Ar} / \mathrm{O}_{2}, \mathrm{~N}_{2} / \mathrm{O}_{2}$, and $\mathrm{Ar} / \mathrm{N}_{2}=80 / 20,60 / 40,40 / 60$, and 49 $20 / 80 \%$.

A pulsed high voltage with a pulse width of $500 \mathrm{~ns} 51$ generated by a Blumlein generator, which has two coaxial 52 transmission lines (Fujikura 5D-2V) with a length of $50 \mathrm{~m} 53$ and a capacitance of $5 \mathrm{nF}$, was applied to the needle electrode 54 to generate the pulsed discharge above the water surface. The 55 coaxial transmission lines were charged to a negative voltage 56 of $14.14 \mathrm{kV}$, and the pulse repetition rate was $20 \mathrm{pps}$ (pulse 57 per second). The applied voltage was measured using a high- 58 voltage probe (Iwatsu Test Instruments HV-P30) and the 59 discharge current was obtained by measuring the voltage 60 drop across a non-inductive resistor connected in series 61 


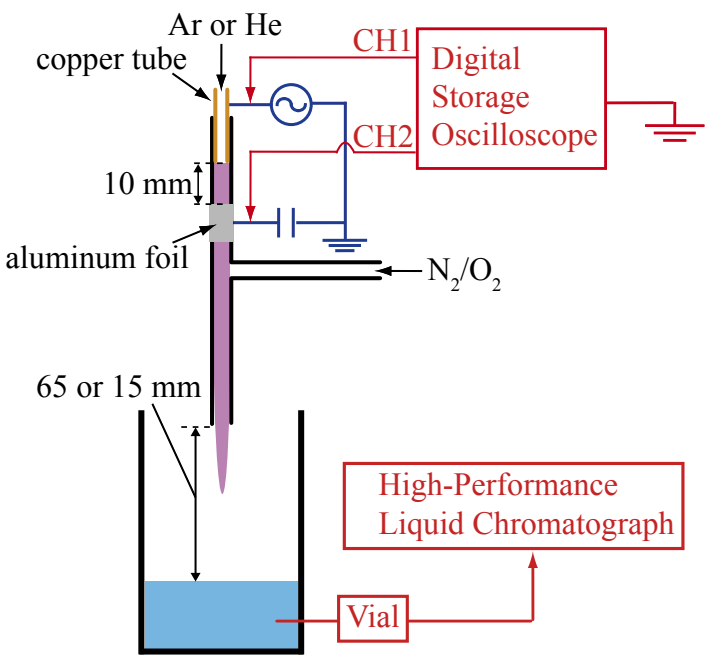

Fig. 1. (Color online) Schematic diagram of experimental apparatus for ${ }^{8}$ plasma jet.

19

20

21 between the bath electrode and the ground. The input power 22 was calculated by multiplying the applied voltage and ${ }_{23}$ discharge current, and the input energy was obtained from 24 the time integration of the input energy. Water samples of $251.2 \mathrm{~mL}$ were taken after plasma exposure and analyzed using 26 a high-performance liquid chromatograph (HPLC; Shimadzu 27 Prominence) equipped with an ion chromatography column 28 (Shodex IC NI-424) in combination with an autosampler. The 29 eluent of the HPLC was a mixed solution of $3 \mathrm{mmol} / \mathrm{L}$ acetic 30 acid and $1.9 \mathrm{mmol} / \mathrm{L}$ potassium hydroxide, and the wave31 length of the absorbance detector was fixed at $220 \mathrm{~nm}$.

\section{з3 2.2 Corona discharge}

34 The experimental apparatus for a corona discharge is similar 35 to that used in a previous work. ${ }^{12)}$ A comb-shaped electrode and a plastic container were placed in an acrylic discharge chamber with a length of $140 \mathrm{~mm}$, a width of $260 \mathrm{~mm}$, and a height of $100 \mathrm{~mm}$. The comb-shaped electrode consisted of four clusters, each of which has $26(13 \times 2)$ combs, with a width of $1.6 \mathrm{~mm}$ and a length of $15 \mathrm{~mm}$, placed at intervals of $4 \mathrm{~mm}$. Deionized water of $100 \mathrm{~mL}$ was poured into the container, and the distance between the tip of the electrode and the water surface was fixed at $15 \mathrm{~mm}$. An aluminum foil 44 was immersed into the water and earthed. A gas mixture of ${ }_{45} \mathrm{~N}_{2} / \mathrm{O}_{2}$ or $\mathrm{Ar} / \mathrm{O}_{2}$ was used as a $\mathrm{BG}$ gas and fed into the 46 chamber at a constant flow rate of $2 \mathrm{~L} / \mathrm{min}$. The $\mathrm{BG}$ gas 47 mixture ratios were $\mathrm{Ar} / \mathrm{O}_{2}=80 / 20,60 / 40$, and $40 / 60 \%$, and ${ }_{48} \mathrm{~N}_{2} / \mathrm{O}_{2}=60 / 40$ and $40 / 60 \%$. A positive DC high voltage 49 of $14.7-15.4 \mathrm{kV}$ was applied to the electrode to generate a 50 corona discharge between the electrode and the water surface, 51 with an input power of $6 \mathrm{~W}$. The input energy was obtained 52 from the time integration of the input power. Water samples of 53 $1.2 \mathrm{~mL}$ were analyzed using the HPLC after plasma exposure.

\subsection{Plasma jet}

${ }_{56}$ Figure 1 shows a schematic diagram of the experimental 57 apparatus for the plasma jet. The atmospheric pressure 58 plasma jet reactor consisted of a T-shaped glass tube, a 59 copper tube, and an aluminum sheet. The copper tube was so inserted into an end of the main tube of the T-shaped glass 61 tube, and the aluminum sheet was bound around the main tube and earthed. The gap length between the copper tube and the aluminum sheet was fixed at $10 \mathrm{~mm}$. An Ar or He gas was fed into the main tube through the copper tube at a constant flow rate of 10 or $5 \mathrm{~L} / \mathrm{min}$, respectively. A gas mixture of $\mathrm{N}_{2} / \mathrm{O}_{2}$, the mixture ratio of which is $\mathrm{N}_{2} / \mathrm{O}_{2}=$ $100 / 0,80 / 20,60 / 40,40 / 60,20 / 80$, and $0 / 100 \%$, was mixed into the plasma jet from the side tube of the T-shaped glass tube at a constant flow rate of $0.1 \mathrm{~L} / \mathrm{min}$.

An AC high voltage of 6.0-7.0 kV amplitude generated by 9 a neon-sign transformer (Kodera Electronics CR-N16) was 10 applied to the copper tube to generate the plasma jet. The 11 input power was calculated by the Lissajous figure method, ${ }^{13)}{ }_{12}$ and the input energy was obtained from the time integration 13 of the input power. The applied voltage was measured using 14 a high-voltage probe (Tektronix P6015A), and the charge 15 amount was obtained by measuring the voltage drop across a 16 ceramic capacitor with a capacitance of $10 \mathrm{nF}$, connected in 17 series between the aluminum sheet and the ground. The 18 voltage drop was measured using a high-voltage differential 19 probe (GW Instek GDP-100). Deionized water of $200 \mathrm{~mL} 20$ was poured into a beaker placed below the plasma jet. The ${ }_{21}$ distance between the water surface and the outlet end of the 22 main tube was fixed at 65 or $15 \mathrm{~mm}$. The Ar gas flow rate was 23 fixed at $5 \mathrm{~L} / \mathrm{min}$ when the distance was fixed at $15 \mathrm{~mm}$. The 24 water was exposed to the plasma jet, and then water samples 25 of $1.2 \mathrm{~mL}$ were taken and analyzed using the HPLC after 26 plasma exposure.

\subsection{Packed-bed dielectric barrier discharge}

The experimental apparatus for a packed-bed dielectric barrier 30 discharge (PB-DBD) is similar to that used in a previous 31 work. ${ }^{14)}$ A PB-DBD reactor consisted of a glass tube filled 32 with soda-lime glass balls, an inner rod electrode, and an outer 33 mesh electrode. The diameters of the glass tube, glass balls, 34 and rod electrode were 22, 3.0, and $2.0 \mathrm{~mm}$, respectively. Ar, 35 $\mathrm{N}_{2}, \mathrm{O}_{2}$, or a gas mixture of $\mathrm{Ar} / \mathrm{O}_{2}, \mathrm{~N}_{2} / \mathrm{O}_{2}$, or $\mathrm{Ar} / \mathrm{N}_{2}$ was 36 used as a BG gas and fed into the reactor at a constant flow 37 rate of $2 \mathrm{~L} / \mathrm{min}$. The gas mixture ratios were $\mathrm{Ar} / \mathrm{O}_{2}, \mathrm{~N}_{2} / \mathrm{O}_{2}, 38$ and $\mathrm{Ar} / \mathrm{N}_{2}=80 / 20,60 / 40,40 / 60$, and $20 / 80 \%$.

A sinusoidal high voltage of $5.7-12.0 \mathrm{kV}$ amplitude 40 generated by the neon-sign transformer was applied between 41 electrodes to generate the PB-DBD. The input energy was 42 obtained from the time integration of input power calculated 43 by the Lissajous figure method. The off-gas from the reactor 44 was introduced through a Teflon tube with a length of $60 \mathrm{~cm} 45$ and an inner diameter of $3.96 \mathrm{~mm}$ and sparged into deionized 46 water of $100 \mathrm{~mL}$ in a flask. Water samples of $1.2 \mathrm{~mL}$ were 47 taken and analyzed using the HPLC after off-gas sparging. 48 Furthermore, the PB-DBD off-gas was analyzed using a 49 Fourier transform infrared spectrophotometer (JASCO FT/ 50 IR-4200) equipped with a gas cell (Infrared Analysis 10-PA), 51 which has an optical path length of $10 \mathrm{~m}$.

\section{Results and discussion}

In HPLC analysis, $\mathrm{H}_{2} \mathrm{O}_{2}, \mathrm{NO}_{2}{ }^{-}$, and $\mathrm{NO}_{3}{ }^{-}$were detected in 55 the sampled water. Figure 2 shows the $\mathrm{H}_{2} \mathrm{O}_{2}$ concentrations 56 in the sampled water as functions of specific energy, which is 57 defined as the input energy per unit volume of water. $\mathrm{H}_{2} \mathrm{O}_{2} 58$ was produced in the cases of pulsed discharge, corona 59 discharge, and plasma jet, but not in the case of PB-DBD off- 60 gas sparging; therefore, short-lifetime active and/or energetic 61 


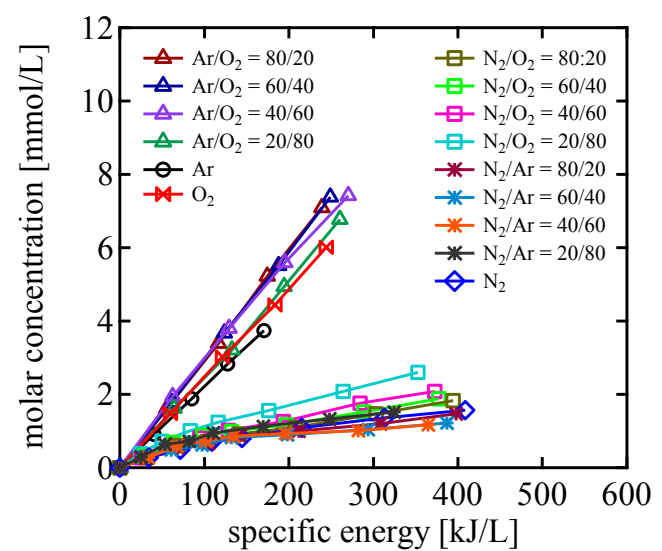

(a)

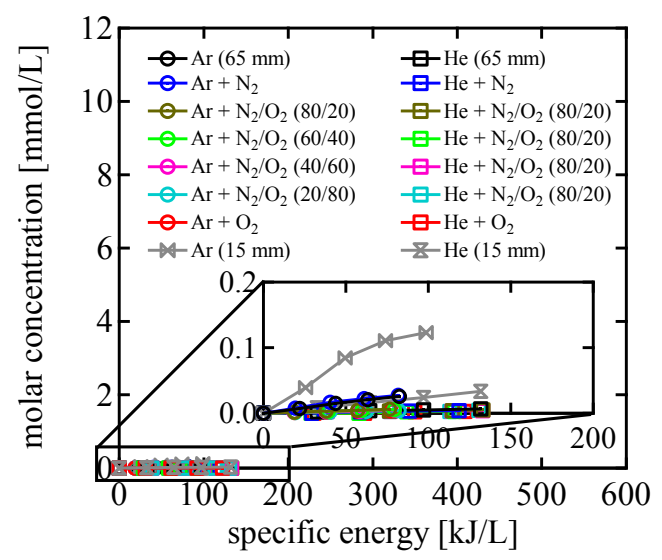

(c)

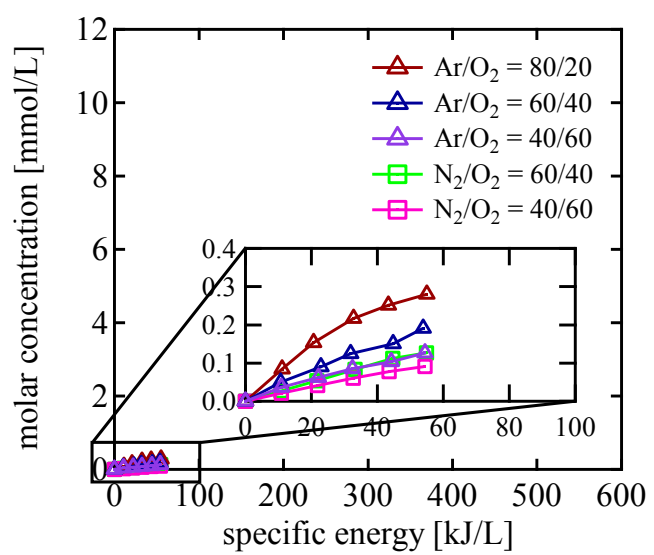

(b)

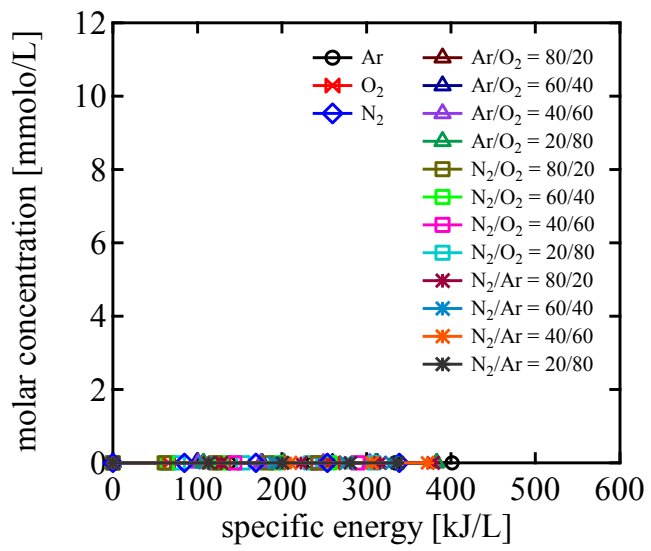

(d)

Fig. 2. (Color online) $\mathrm{H}_{2} \mathrm{O}_{2}$ concentrations in sampled water as functions of specific energy: (a) pulsed discharge, (b) corona discharge, (c) plasma jet, and ${ }_{31}$ (d) PB-DBD.

species in the plasma in contact with water probably contribute to $\mathrm{H}_{2} \mathrm{O}_{2}$ production. When water is exposed to plasma, vaporized water molecules can be dissociated as follows: ${ }^{15-17)}$

$$
\begin{aligned}
& \mathrm{H}_{2} \mathrm{O}+\mathrm{e} \rightarrow \mathrm{OH}+\mathrm{H}+\mathrm{e}, \\
& \mathrm{H}_{2} \mathrm{O}+\mathrm{e} \rightarrow \mathrm{H}_{2} \mathrm{O}^{+}+2 \mathrm{e}, \\
& \mathrm{H}_{2} \mathrm{O}^{+}+\mathrm{H}_{2} \mathrm{O} \rightarrow \mathrm{H}_{3} \mathrm{O}^{+}+\mathrm{OH} .
\end{aligned}
$$

42 Then, $\mathrm{H}_{2} \mathrm{O}_{2}$ can be produced from $\mathrm{OH}$ radicals represented 4 as $^{18,19)}$

$$
\mathrm{OH}+\mathrm{OH} \rightarrow \mathrm{H}_{2} \mathrm{O}_{2} \quad\left(k=1.5 \times 10^{-11} \mathrm{~cm}^{3} \cdot \mathrm{mol}^{-1} \cdot \mathrm{s}^{-1}\right)
$$

46 where $k$ is the rate constant. Although water vapor is 47 contained within the concentration of $20 \mathrm{ppm}$ as impurities in 48 the $\mathrm{BG}$ gas of the $\mathrm{PB}-\mathrm{DBD}$, the concentration of $\mathrm{OH}$ radicals 49 can be quite small, so that $\mathrm{H}_{2} \mathrm{O}_{2}$ produced by the reaction 50 shown by Eq. (4) is negligible.

$\mathrm{H}_{2} \mathrm{O}_{2}$ concentrations in the pulsed discharge monotonically 52 increased with the specific energy, while the amount of $\mathrm{H}_{2} \mathrm{O}_{2}$ ${ }_{53}$ in the $\mathrm{BG}$ gas containing $\mathrm{N}_{2}$ was found to be smaller than that 54 in the other $\mathrm{BG}$ gas. This may be due to the inhibition of ${ }_{55} \mathrm{H}_{2} \mathrm{O}_{2}$ production by species containing $\mathrm{N}$ atom(s). The $\mathrm{H}_{2} \mathrm{O}_{2}$ 56 production efficiency of $31.2 \mu \mathrm{mol} / \mathrm{kJ}$ at a maximum was 57 obtained when an $\mathrm{Ar} / \mathrm{O}_{2}$ mixture was used. The $\mathrm{H}_{2} \mathrm{O}_{2}$ 58 concentrations in the corona discharge tended to increase 59 with $\mathrm{Ar}$ or $\mathrm{N}_{2}$ content in the mixture gas, and the maximum ${ }_{60} \mathrm{H}_{2} \mathrm{O}_{2}$ production efficiency of $7.6 \mu \mathrm{mol} / \mathrm{kJ}$ was obtained in ${ }_{61} \mathrm{Ar} / \mathrm{O}_{2}=80 / 20 \%$. When the plasma jet was used, the amount of $\mathrm{H}_{2} \mathrm{O}_{2}$ was small and slightly increased with the shortening 34 of the distance between the plasma and the water surface. The 35 $\mathrm{H}_{2} \mathrm{O}_{2}$ production efficiency in $\mathrm{Ar}$ without the $\mathrm{N}_{2} / \mathrm{O}_{2}$ mixture 36 was $1.7 \mu \mathrm{mol} / \mathrm{kJ}$, which is significantly lower than that in ${ }_{37}$ pulsed discharge. Van Gils et al. ${ }^{5)}$ investigated the $\mathrm{H}_{2} \mathrm{O}_{2} 38$ concentrations in water exposed to an Ar plasma jet, and 39 reported that the $\mathrm{H}_{2} \mathrm{O}_{2}$ production efficiency was $0.7 \mu \mathrm{mol} / \mathrm{kJ} 40$ at a maximum. This value differs slightly from the efficiency 41 of this work, so that pulsed discharge may be suitable for 42 highly efficient $\mathrm{H}_{2} \mathrm{O}_{2}$ production.

Figure 3 shows the $\mathrm{NO}_{2}^{-}$concentrations in the sampled 44 water as functions of specific energy. $\mathrm{NO}_{2}{ }^{-}$was produced by 45 exposure to the pulsed discharge, corona discharge, and 46 plasma jet when the $\mathrm{BG}$ gas contained $\mathrm{N}_{2}$, but not by the 47 sparging of the PB-DBD off-gas; therefore, short-lifetime 48 active and/or energetic species in the plasma in contact with 49 water probably contribute to $\mathrm{NO}_{2}{ }^{-}$production. Furthermore, 50 the $\mathrm{NO}_{2}{ }^{-}$concentration in the pulsed discharge was found 51 to increase and then decrease with the increase in specific 52 energy. When water is exposed to plasma in the BG gas 53 containing $\mathrm{N}_{2}$, the following reactions ${ }^{20)}$ can occur:

$$
\begin{aligned}
& \mathrm{N}_{2}+\mathrm{e}(\text { fast }) \rightarrow 2 \mathrm{~N}+\mathrm{e}(\text { slow }), \\
& \mathrm{N}+\mathrm{OH} \rightarrow \mathrm{NO}+\mathrm{H} \\
& \quad\left(k=4.9 \times 10^{-11} \mathrm{~cm}^{3} \cdot \mathrm{mol}^{-1} \cdot \mathrm{s}^{-1}\right), \\
& \mathrm{NO}+\mathrm{OH}+\mathrm{M} \rightarrow \mathrm{HNO}_{2}+\mathrm{M} \\
& \quad\left(k=7.4 \times 10^{-31} \mathrm{~cm}^{6} \cdot \mathrm{mol}^{-2} \cdot \mathrm{s}^{-1}\right),
\end{aligned}
$$




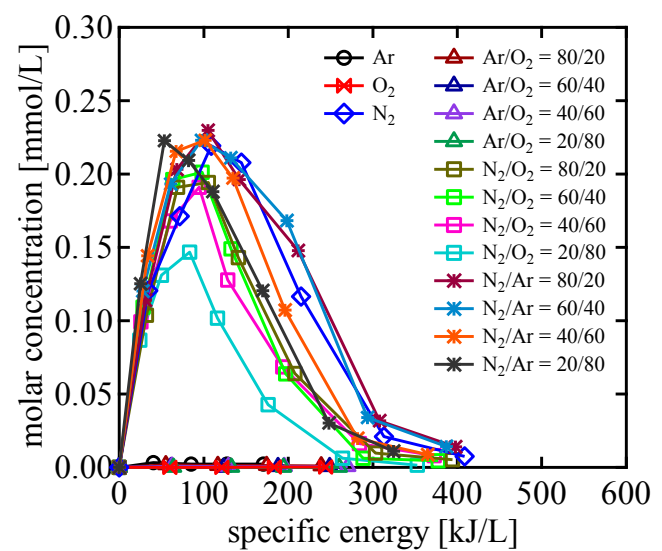

(a)

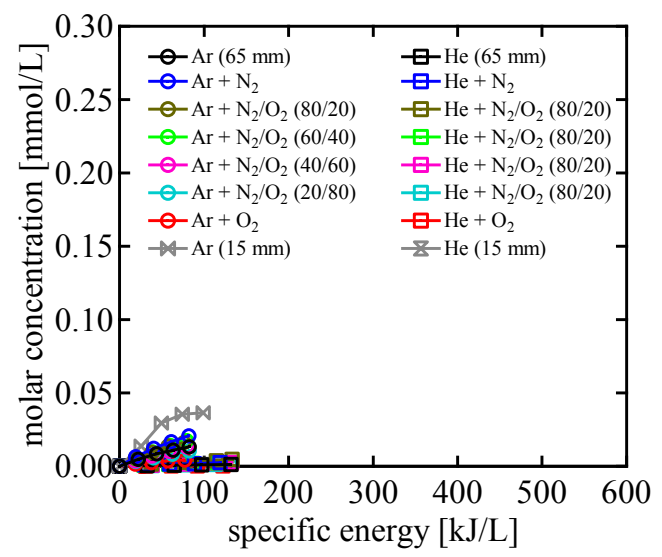

(c)

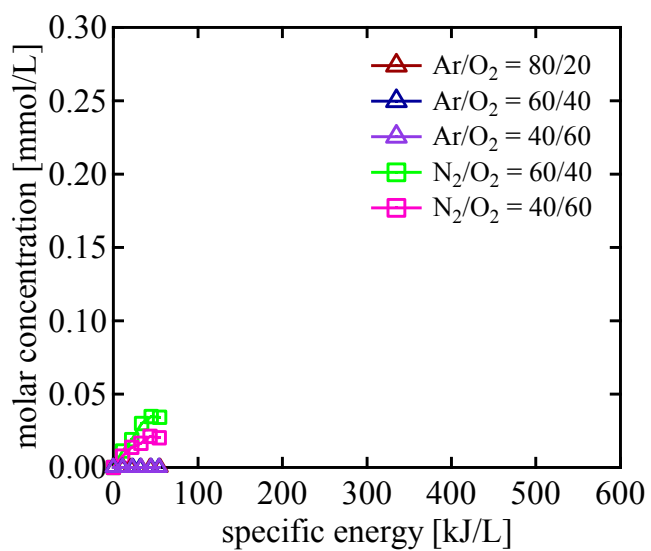

(b)

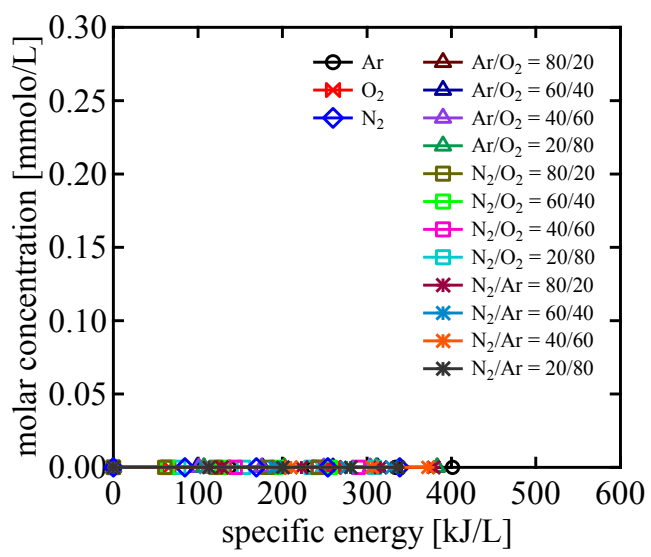

(d)

Fig. 3. (Color online) $\mathrm{NO}_{2}^{-}$concentrations in sampled water as functions of specific energy: (a) pulsed discharge, (b) corona discharge, (c) plasma jet, and 31 (d) PB-DBD.

where $\mathrm{M}$ is the third body. Then, $\mathrm{HNO}_{2}$ dissolves in water and dissociates into $\mathrm{NO}_{2}^{-}$and $\mathrm{H}^{+}$in acid-base equilibrium $\left(\mathrm{p} K_{\mathrm{a}}=3.3\right)$ represented by ${ }^{5,21)}$

$$
\mathrm{HNO}_{2} \rightleftarrows \mathrm{NO}_{2}{ }^{-}+\mathrm{H}^{+} \text {. }
$$

Furthermore, $\mathrm{HNO}_{2}$ reacts with $\mathrm{H}_{2} \mathrm{O}_{2}$ to form $\mathrm{HOONO}$ by $^{5,22)}$

$$
\mathrm{HNO}_{2}+\mathrm{H}_{2} \mathrm{O}_{2} \rightarrow \mathrm{HOONO}+\mathrm{H}_{2} \mathrm{O} .
$$

$\mathrm{HOONO}$ is an unstable species and rapidly turns into $\mathrm{NO}_{3}{ }^{-}$ and $\mathrm{H}^{+}$. 22)

$$
\mathrm{HOONO} \rightarrow \mathrm{NO}_{3}^{-}+\mathrm{H}^{+} .
$$

${ }_{48}$ In this work, the $\mathrm{pH}$ drop of the water after pulsed discharge 49 exposure was observed, and the $\mathrm{pH}$ decreased below 4.0 after 50 $5 \mathrm{~min}$ exposure (corresponding to a specific energy of 32 $51 \mathrm{~kJ} / \mathrm{L}$ ) and 3.0 after $30 \mathrm{~min}$ exposure (corresponding to a 52 specific energy of $208 \mathrm{~kJ} / \mathrm{L}$ ) in $\mathrm{N}_{2} / \mathrm{O}_{2}=80 / 20 \%$. Therefore, ${ }_{53} \mathrm{NO}_{2}{ }^{-}$in the water may be converted into $\mathrm{NO}_{3}{ }^{-}$through the 54 reactions shown by Eqs. (8)-(10), resulting in the drop of 55 the $\mathrm{NO}_{2}{ }^{-}$concentration with the increase in specific energy. $56 \mathrm{NO}_{2}{ }^{-}$concentrations in the corona discharge and plasma jet 57 showed a tendency to saturate, and this result is also probably ${ }_{58}$ due to the drop in the $\mathrm{pH}$ of the water. The maximum $\mathrm{NO}_{2}{ }^{-}$ 59 production efficiency of $5.0 \mu \mathrm{mol} / \mathrm{kJ}$ was obtained using the 6o pulsed discharge in $\mathrm{N}_{2} / \mathrm{Ar}=20 / 80 \%$ at the specific energy 61 of $25 \mathrm{~kJ} / \mathrm{L}$.
In the PB-DBD, the BG gas contains water vapor within 35 the concentration of $20 \mathrm{ppm}$ as impurities, and the concen- 36 tration is six orders of magnitude lower than that of $\mathrm{N}_{2}$. $\mathrm{OH}_{37}$ radicals can be produced from a trace of water vapor, but 38 the concentration of $\mathrm{OH}$ radicals can be much lower than that 39 of $\mathrm{N}$ atoms produced from $\mathrm{N}_{2}$ in the PB-DBD; therefore, the 40 reaction shown by Eq. (4) can be negligible and the reactions 41 shown by Eqs. (6) and (7) can occur. However, $\mathrm{NO}_{2}{ }^{-}$was 42 not detected, so that the concentration of $\mathrm{NO}_{2}{ }^{-}$in the water 43 was below the detection limit $(20 \mathrm{nmol} / \mathrm{L})$ or $\mathrm{NO}_{2}{ }^{-}$was 44 rapidly converted into other species.

Figure 4 shows the $\mathrm{NO}_{3}{ }^{-}$concentrations in the sampled 46 water as functions of specific energy. When water is exposed 47 to plasma in the $\mathrm{BG}$ gas containing $\mathrm{N}_{2}$, the following 48 reactions ${ }^{18,23)}$ may occur in addition to the reactions shown 49 by Eqs. (5)-(7):

$$
\begin{aligned}
& \mathrm{NO}+\mathrm{O}+\mathrm{M} \rightarrow \mathrm{NO}_{2}+\mathrm{M} \\
& \quad\left(k=8.9 \times 10^{-32} \mathrm{~cm}^{6} \cdot \mathrm{mol}^{-2} \cdot \mathrm{s}^{-1}\right), \\
& \mathrm{NO}_{2}+\mathrm{OH}+\mathrm{M} \rightarrow \mathrm{HNO}_{3}+\mathrm{M} \\
& \quad\left(k=2.6 \times 10^{-30} \mathrm{~cm}^{6} \cdot \mathrm{mol}^{-2} \cdot \mathrm{s}^{-1}\right) .
\end{aligned}
$$

Then, $\mathrm{HNO}_{3}$ dissolves in water and completely dissociates 57 into $\mathrm{NO}_{3}^{-}$and $\mathrm{H}^{+}$. The reactions shown by Eqs. (8)-(10) 58 also contribute to $\mathrm{NO}_{3}{ }^{-}$production. Furthermore, the pro- 59 duction of $\mathrm{HNO}_{2}$ and $\mathrm{HNO}_{3}$ by the reactions shown by 60 Eqs. (7) and (12) causes $\mathrm{OH}$ consumption, so that $\mathrm{H}_{2} \mathrm{O}_{2} 61$ 


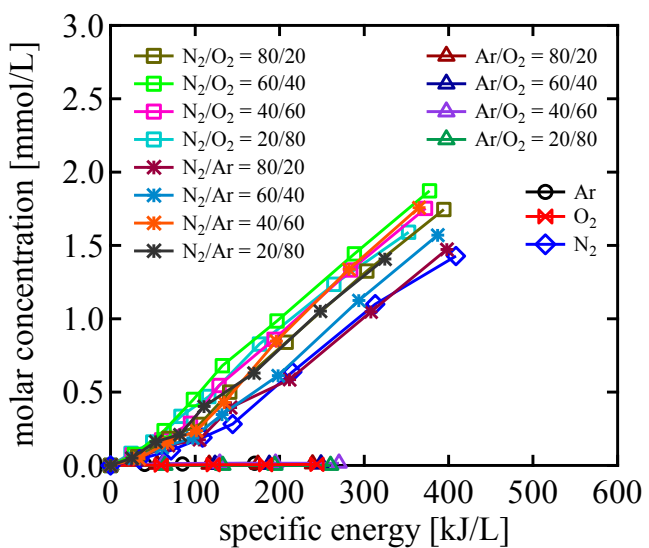

(a)

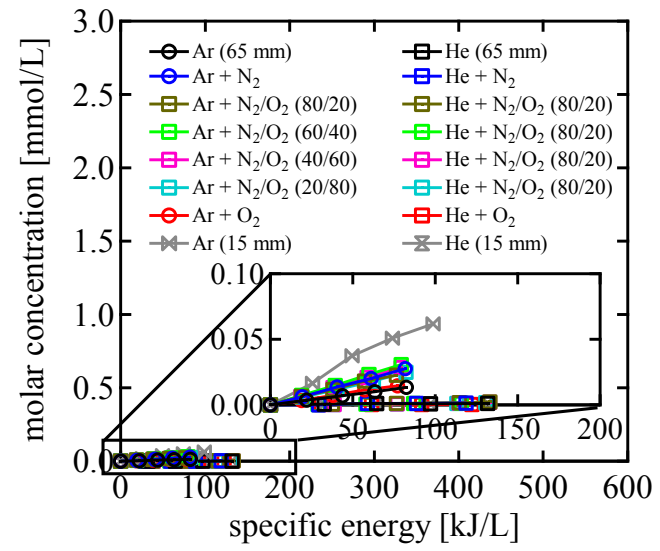

(c)

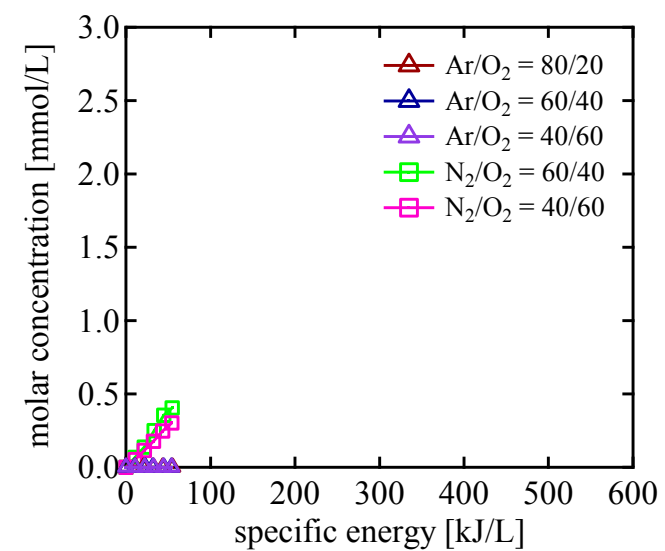

(b)

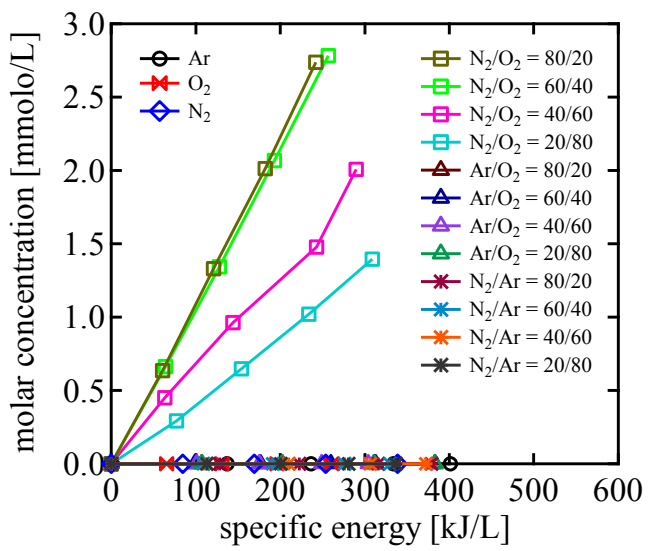

(d)

Fig. 4. (Color online) $\mathrm{NO}_{3}{ }^{-}$concentrations in sampled water as functions of specific energy: (a) pulsed discharge, (b) corona discharge, (c) plasma jet, and ${ }_{31}^{30}$ (d) PB-DBD.

36 production by the reaction shown by Eq. (4) is inhibited, 37 resulting in the decrease in the $\mathrm{H}_{2} \mathrm{O}_{2}$ amount in the $\mathrm{BG}$ gas 38 containing $\mathrm{N}_{2}$.

$\mathrm{NO}_{3}{ }^{-}$was also produced by off-gas sparging. In the PB$40 \mathrm{DBD}$, a trace of $\mathrm{OH}$ radicals is produced from water vapor ${ }_{41}$ contained in the BG gas as impurities, as described above, so 42 that the reaction shown by Eq. (12) has little contribution to ${ }_{43} \mathrm{HNO}_{3}$ production. Thus, other reactions by long-lifetime 44 species to produce $\mathrm{NO}_{3}{ }^{-}$may occur in off-gas sparging. The ${ }_{45} \mathrm{NO}_{3}{ }^{-}$concentrations in the pulsed discharge monotonically 46 increased with the specific energy, and the $\mathrm{NO}_{3}{ }^{-}$production 47 efficiency of $5.1 \mu \mathrm{mol} / \mathrm{kJ}$ was obtained at a maximum. In the 48 corona discharge, $\mathrm{NO}_{3}{ }^{-}$tended to increase with $\mathrm{Ar}$ or $\mathrm{N}_{2}$ 49 content in the mixture gas, and the $\mathrm{NO}_{3}{ }^{-}$production so efficiency of $8.0 \mu \mathrm{mol} / \mathrm{kJ}$ was obtained. When the plasma 51 jet was used, the amount of $\mathrm{NO}_{3}{ }^{-}$was small and slightly 52 increased with $\mathrm{N}_{2}$ mixing. In the case of off-gas sparging, ${ }_{53} \mathrm{NO}_{3}{ }^{-}$was produced in the $\mathrm{N}_{2} / \mathrm{O}_{2}$ mixture and its amount 54 was found to increase with $\mathrm{N}_{2}$ content. The maximum $55 \mathrm{NO}_{3}{ }^{-}$production efficiency of $11.3 \mu \mathrm{mol} / \mathrm{kJ}$ was obtained in ${ }_{56} \mathrm{~N}_{2} / \mathrm{O}_{2}=80 / 20 \%$.

Figure 5 shows the absorbance spectra of the PB-DBD 58 off-gas before and after sparging, obtained by infrared 59 absorption spectroscopy. Absorption peaks corresponding to 60 nitrous oxide $\left.\left(\mathrm{N}_{2} \mathrm{O} ; 2224 \mathrm{~cm}^{-1}\right),{ }^{24}\right)$ dinitrogen pentaoxide ${ }_{61}\left(\mathrm{~N}_{2} \mathrm{O}_{5} ; 1247,1704\right.$, and $\left.\left.1745 \mathrm{~cm}^{-1}\right),{ }^{25}\right) \mathrm{HNO}_{3}(1312,1346$, and $\left.1698 \mathrm{~cm}^{-1}\right){ }^{26)}$ and $\mathrm{O}_{3}\left(1042 \mathrm{~cm}^{-1}\right)^{27)}$ were detected in 36 the $\mathrm{N}_{2} / \mathrm{O}_{2}$ mixture. It was suggested above that a trace of ${ }_{37}$ $\mathrm{NO}_{2}{ }^{-}$might be produced in water via the reaction shown 38 by Eq. (7); however, $\mathrm{NO}_{2}^{-}$was not detected. $\mathrm{O}_{3}$ was 39 observed in the off-gas as shown in Fig. 5 and $\mathrm{O}_{3}$ can 40 dissolve in water; therefore, the reaction shown by Eq. (13) 41 can occur. ${ }^{28)}$

$$
\mathrm{NO}_{2}{ }^{-}+\mathrm{O}_{3} \rightarrow \mathrm{NO}_{3}{ }^{-}+\mathrm{O}_{2} \text {. }
$$

Furthermore, considering that $\mathrm{NO}_{2}{ }^{-}$was not detected, the 45 rate of reaction can be sufficiently high.

It was described that a trace of $\mathrm{HNO}_{3}$ is produced via the 47 reaction shown by Eq. (12). In addition, $\mathrm{HNO}_{3}$ may also be 48 produced by the reaction shown by Eq. (14), ${ }^{18)}$ since $\mathrm{N}_{2} \mathrm{O}_{5} 49$ and water vapor are contained in the off-gas before sparging, 50 as shown in Fig. 5.

$$
\mathrm{N}_{2} \mathrm{O}_{5}+\mathrm{H}_{2} \mathrm{O} \rightarrow 2 \mathrm{HNO}_{3} .
$$

The intensities of absorption peaks corresponding to $\mathrm{N}_{2} \mathrm{O}_{5} 54$ and $\mathrm{HNO}_{3}$ were reduced by sparging, while there were little 55 changes in the intensities of absorption peaks corresponding 56 to $\mathrm{N}_{2} \mathrm{O}$ and $\mathrm{O}_{3}$. This indicates that $\mathrm{HNO}_{3}$ in the off-gas 57 dissolves in water and $\mathrm{HNO}_{3}$ is produced in liquid phase 58 by the reaction shown by Eq. (14), contributing to $\mathrm{NO}_{3}{ }^{-}{ }_{59}$ production, and that $\mathrm{N}_{2} \mathrm{O}$ and $\mathrm{O}_{3}$ do not produce ROS/RNS 60 in water. 


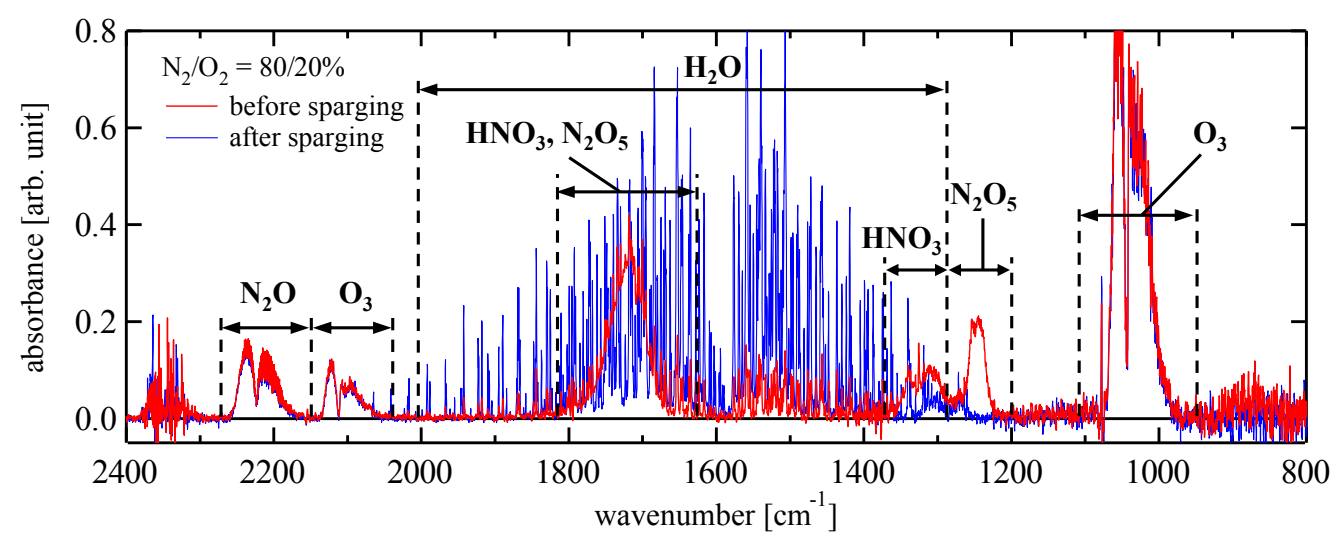

Fig. 5. (Color online) Absorbance spectra of PB-DBD off-gas before and after sparging.

\section{Conclusions}

19 We have investigated reactive oxygen species and reactive 20 nitrogen species (ROS/RNS) in water, exposed directly to a ${ }_{21}$ pulsed discharge, a DC corona discharge, and a plasma jet 22 or sparged the off-gas of a packed-bed dielectric barrier ${ }_{23}$ discharge (PB-DBD). $\mathrm{H}_{2} \mathrm{O}_{2}, \mathrm{NO}_{2}^{-}$, and $\mathrm{NO}_{3}{ }^{-}$are produced 24 after plasma exposure and only $\mathrm{NO}_{3}{ }^{-}$after off-gas sparging. 25 Short-lifetime species in plasma such as $\mathrm{OH}$ radicals act as 26 the precursors of $\mathrm{H}_{2} \mathrm{O}_{2}$ and $\mathrm{NO}_{2}{ }^{-}$, and long-lifetime species 27 including $\mathrm{N}_{2} \mathrm{O}_{5}$ act as the precursor of $\mathrm{NO}_{3}{ }^{-}$. $\mathrm{NO}_{x}$ may 28 inhibit $\mathrm{H}_{2} \mathrm{O}_{2}$ production through $\mathrm{OH}$ consumption to produce $29 \mathrm{HNO}_{2}$ and $\mathrm{HNO}_{3} \cdot \mathrm{O}_{3}$ is found not to be the precursor of ROS/RNS. In this work, the highest production efficiencies of $\mathrm{H}_{2} \mathrm{O}_{2}$ and $\mathrm{NO}_{2}{ }^{-}$are obtained to be 31.2 and $5.0 \mu \mathrm{mol} / \mathrm{kJ}$, respectively, by pulsed-plasma exposure, and that of $\mathrm{NO}_{3}{ }^{-}$is 33 obtained to be $11.3 \mu \mathrm{mol} / \mathrm{kJ}$ by the off-gas sparging of the PB-DBD.

\section{Acknowledgment}

This work is partially supported by The Royal Society International Exchanges Scheme.

1) M. Naïtali, G. Kamgang-Youbi, J.-M. Herry, M.-N. Bellon-Fontaine, and J.-L. Brisset, Appl. Environ. Microbiol. 76, 7662 (2010).

2) D. P. Park, K. Davis, S. Gilani, C.-A. Alonzo, D. Dobrynin, G. Friedman, A. Fridman, A. Rabinovich, and G. Fridman, Curr. Appl. Phys. 13, S19 (2013).

3) H.-S. Kim, K. C. Wright, I.-W. Hwang, D.-H. Lee, A. Rabinovich, A. Fridman, and Y. I. Cho, Int. Commun. Heat Mass Transfer 42, 5 (2013).

4) Q. Zhang, Y. Liang, H. Feng, R. Ma, Y. Tian, J. Zhang, and J. Fang, Appl. Phys. Lett. 102, 203701 (2013).

5) C. A. J. van Gils, S. Hofmann, B. K. H. L. Boekema, R. Brandenburg, and P. J. Bruggeman, J. Phys. D 46, 175203 (2013).
6) S. Mohades, M. Laroussi, J. Sears, N. Barekzi, and H. Razavi, Phys. Plasmas 22, 122001 (2015).

7) A. Kojtari, U. K. Ercan, J. Smith, G. Friedman, R. B. Sensenig, S. Tyagi, 19 S. G. Joshi, H.-F. Ji, and A. D. Brooks, J. Nanomed. Biother. Discov. 4, 12020 (2013).

8) M. J. Traylor, M. J. Pavlovich, S. Karim, P. Hait, Y. Sakiyama, D. S. Clark, ${ }^{21}$ and D. B. Graves, J. Phys. D 44, 472001 (2011).

9) K. Takaki, Dennetsu 51, 64 (2012) [in Japanese].

10) K. Matsui, N. Ikenaga, and N. Sakudo, Jpn. J. Appl. Phys. 54, 01 AG06 (2015).

11) H. Shiota, H. Itabashi, K. Satoh, and H. Itoh, Electr. Eng. Jpn. 184 [1], $1^{25}$ (2013).

12) Y. Itoh, K. Satoh, and H. Itoh, Denki Gakkai Ronbunshi A 132, 807 (2012) 27 [in Japanese].

13) H.-E. Wagner, R. Brandenburg, K. V. Kozlov, A. Sonnenfeld, P. Michel, ${ }^{28}$ and J. F. Behnke, Vacuum 71, 417 (2003).

14) K. Takahashi, K. Satoh, and H. Itoh, IEEJ Trans. Fundam. Mater. 134, 6030 (2014).

15) Y. Itikawa and N. Mason, J. Phys. Chem. Ref. Data 34, 1 (2005).

16) W. Lindinger, Phys. Rev. A 7, 328 (1973).

17) R. P. Joshi and S. M. Thagard, Plasma Chem. Plasma Process. 33, 17 (2013).

18) R. Atkinson, D. L. Baulch, R. A. Cox, J. N. Crowley, R. F. Hampson, R. G. 35 Hynes, M. E. Jenkin, M. J. Rossi, and J. Troe, Atmos. Chem. Phys. 4, 1461 (2004).

19) S. Mededovic and B. R. Locke, J. Phys. D 40, 7734 (2007).

20) R. Atkinson, D. L. Baulch, R. A. Cox, R. F. Hampson, Jr., J. A. Kerr, and 38 J. Troe, J. Phys. Chem. Ref. Data 18, 881 (1989).

21) P. Lukes, E. Dolezalova, I. Sisrova, and M. Clupek, Plasma Sources Sci. Technol. 23, 015019 (2014).

22) S. Goldstein, J. Lind, and G. Marényi, Chem. Rev. 105, 2457 (2005). 41

23) L. D'Ottone, P. Campuzano-Jost, D. Bauer, and A. J. Hynes, J. Phys. Chem. 42 A 105, 10538 (2001).

24) T. Shimanouchi, Tables of Molecular Vibrational Frequencies Consolidated (National Bureau of Standards, Washington, D.C., 1972) Vol. I, p. 9.

25) E. L. Varetti and G. C. Pimentel, J. Chem. Phys. 55, 3813 (1971).

26) W.-J. Chen, W.-J. Lo, B.-M. Cheng, and Y.-P. Lee, J. Chem. Phys. 97, 7167 (1992).

27) T. Shimanouchi, J. Phys. Chem. Ref. Data 6, 993 (1977).

28) S. A. Penkett, Nature 240, 105 (1972). 